\title{
カルクアルカリ火山岸の石基における斜方・単斜 丙輝石の鉱物比を推定する方法
}

\author{
A Procedure for estimation of the mineral ratio of \\ orthopyroxene to sum of both clinopyroxene \\ and orthopyroxene in the groundmass of \\ calc-alkali volcanic rocks
}

$$
\text { 竹下 寿 (Hisasi Takesita)* }
$$

\begin{abstract}
The estimation is essentially made by construction of frequency distribution of the extinction angle, $c \wedge Z^{\prime}$, in random orientations of any pyroxenes which are extracted arbitrarily out of good prismatic crystals in the groundmass of a calc-alkali volcanic rock. By the writer's opinion, the cumulative frequency of $\mathrm{c} \wedge Z^{\prime}$ from $0^{\circ}$ to $20^{\circ}, y(\%)$, is expressed as a linear function of $x(\%)$, the mineral ratio of orthopyroxene to sum of both clinopyroxene and orthopyroxene, the formula being

$$
y=a x+m
$$

where $a=(r-m) / 100$, and $v$ and $m$ represent the cumulative percentages of $c \wedge Z^{\prime}$ from $0^{\circ}$ to $20^{\circ} ; r$ is referred to orthopyroxene (in case of hypersthene, $2 \mathrm{~V}(-)=60^{\circ}, \mathrm{r}=97 \%$, and $r$ is nearly $100 \%$ for bronzite or enstatite), while $m$ to clinopyroxene $(m=1696$ for a clinopyroxene of which $2 \mathrm{~V}(+)=$ $45^{\circ}$ and $c \wedge Z=45^{\circ}$, and $m=24 \%$ when $V=0^{\circ}, c \wedge Z=40^{\circ}$ ). To give an account of these considerations, the writer has obtained the frequency distribution of $c \wedge Z^{\prime}$ of clinopyroxene and orthopyroxene, respectively, and has ascertained that the practical frequency distribution is well coincide with the theoretical distribution constructed by areal measurement among equiextinction angle lines in the Schmidt net. The equi-extinction angle lines are drawn by interpolation among several projected points, which indicate respective values of $c \wedge Z^{\prime}$ calculated from the formula for the extinction angle in an arbitrary orientation (Takesita 1957).

The petrologic significance of the mineral ratio of orthopyroxene to sum of both pyroxenes $(\mathrm{Rh} \times 100 /(\mathrm{Rh}+\mathrm{Mo})$ ) has also been taken into account as an illustration of consolidation process of some calc-alkali magmas.
\end{abstract}

\section{1.まえがき}

火山岩を顕微鏡下で，カルクアルカリ岩系列であるか、ソレアイト系列であるかを判定 する基本的な方法は，石基斜方輝石が存在するか否かをしらべることである（久野 1954）。 もし斜方輝石斑晶または微斑晶のまわりに，単斜輝石（ビジオン輝石であることが多い）

* 福岡県立門司東高等学校 
の反応绿があればもつともよく区別ができる。しかしながら，同一薄片において，斜方

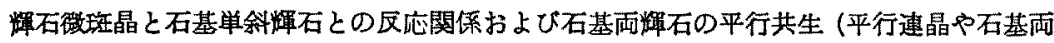

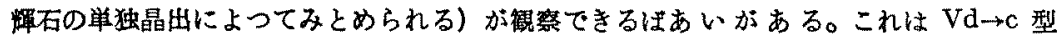
(岩石型の記号は久野（1954）による) とは区別すべきで,さらに刮の見地よりカルクア ルカリ岩, ソレアイト両系列の中間型 (Vc-Vd型) とした（竹下・八末 1961）。カルク アルカリ筫火山告の石基辉石は，斜方輝石がこくかずかにいだされるもの（立武岩貿安 山岩に多い）から，石基耀石がすへて斜方輝石であるもの（珪長資安山岩や石英安山岩に 多いににいたるで，種々の段階がある。また，同ような化学組成でありながら，石基両 輝石の相対量だけは大きな変化をしかす例がある（竹下・八木前出)。カルクフルカリ賀 火山岩の石基両輝石の鉿物比は，岩石成因とくにマグマ噴出期の冷却過程において重要で あると考えられる。

鏡下で，単斜・余方両辉石をみわけるには，まず消光角を測ることである。任意断面で みる斜方辉石の大部分は通消光またはそれに近い值をしめし，同じく戦䣄翚石の大部分は $30^{\circ} \sim 50^{\circ}$ の斜消光をしめす。このばあい，単斜輝石は一般に複屈折度方高く，斜方輝石 は低いので，干涉色を参考にする。石基が粗粒ならば多色性も役だつ。しかし細粒組織の 石基では，多色性を参考にすることはむずかしく，一方干涉色と消光角とを考虑にいれる には、つぎのよな困難点がある。

1) 単斜䡣石でむ切断方向によつては（b 軸に平行またはそれに近い万向），直消光ま

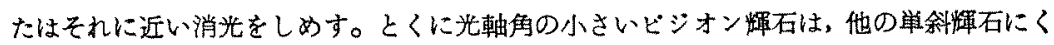
らへ，直消光の割合が高いが，そのばあいの千啮色は，ビシオン輝石の方が，光軸角の大 きい普通輝石にくらへ，比較的高いばあいが多い。また光軸角の大きい普通輝石のなかに は，光軸に垂直またはそれに近い方向でみる杜状結晶もあるので，千涉色があらわれない かまたはきわめて低いものがある。このことは，筆者 (1957) 肪かつてしめした等消光 角線のステレオ投影からも判断できる。

2) 斜方輝石は，壮状の良好な形の結晶の大部分が直消光またはそれに近い消光をしめ し，少量のものは $10^{\circ} \sim 20^{\circ}$ の斜消光をしめす。斜方輝石は一般に千涉色は単斜輝石にく らべて低いが，在意の方向てみる多くの結晶のなかには，周折率の両極值 $(\alpha, \gamma)$ がしめ される方向に㧍かれたものがあつて，干眥色の比較的高いものがある。また単斜輝石は一 般に千涉色は高いが，断面によつては比較的低い干涉色で，かつ小さな消光角（ときに直 消光）をしぬすものがある。斜方・単斜雨輝石が混在するときには，上述の禹方のばあい

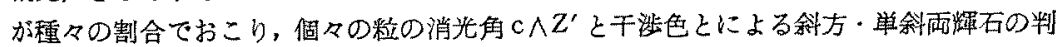
定を图難ならしめる。もちろん自在回転台を使用すればこの困難はとりのぞかれるが， それには多大の時間る要する。

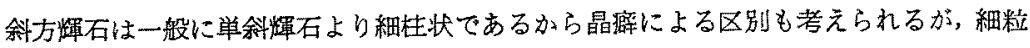
組織の石基ではいずれも同ような晶癖をしめすので，本論にのべる万法で，雨輝石の鉣物 比をもとめるのが安全であると考えられる。

通常 $\mathrm{c}$ 軸にたい乙 $30^{\circ}$ 以内の傾きでお加れた結晶は，柱状の良好な形を呈する。柱状

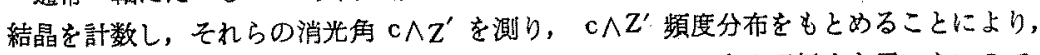
両輝石の存在する割合を求るる力法をのへる。この方法は，自在回枟台を用いないのて， 薄片の全域にわたり，迅速におこなえる。 


\section{2. 巣斜輝石および斜方輝石の $\mathbf{c} \wedge \mathbf{Z}^{\prime}$ 頻度分布}

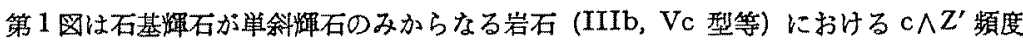

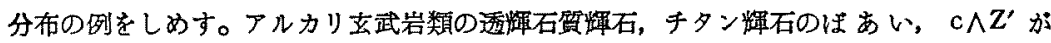
$20^{\circ}$ 以下であるようなぼあいの制合吕 5〜16\% とすくなく，またソレアイト䝷岩石

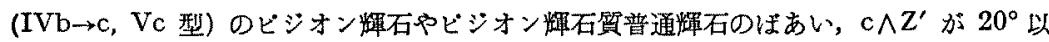
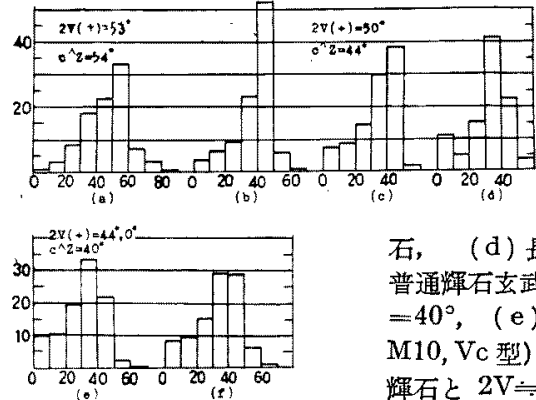

石, 普通輝石立武岩 (IVb 型) 中の石基単斜煇石, $\mathrm{c} \wedge \mathrm{Z}$ $=40^{\circ}$, (e) 長野市 整很路山安山岩 中心部 (No. $\mathrm{M} 10, V_{\mathrm{c}}$ 型) $の$ 石基単斜辉石, $2 \mathrm{~V}(+)=40^{\circ}$ の普通 輝石と $2 \mathrm{~V} \fallingdotseq 0^{\circ}$ のビシオン輝石よりなる, (f) 十

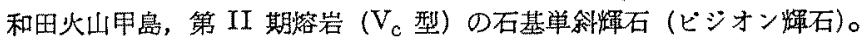

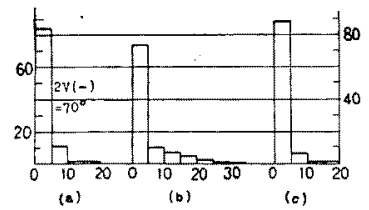

第 2 図斜方輝石の $\mathrm{c} \wedge Z^{\prime}$ 百分率頻度分 布図

（a）香川将国府台譛呫岩（Ve 型）の紫蘇 輝石, (b) 北海道昭和新山石英安山岩 (Ve 型)，（c）十和田火山御验山石英安山 岩 (Ve 型)。

第 1 袁

\begin{tabular}{|c|c|c|}
\hline & (a) & (b) \\
\hline$c \wedge Z^{\prime}$ & 百分率 & 百分率 \\
\hline $\begin{array}{l}0^{\circ} \sim 5^{\circ} \\
5^{\circ} \sim 10^{\circ}\end{array}$ & $\left.\begin{array}{l}4.0 \\
2.6\end{array}\right\} 6.6$ & $\left.\begin{array}{l}59.6 \\
16.6\end{array}\right\} 76.2$ \\
\hline $\begin{array}{l}10^{\circ} \sim 15^{\circ} \\
15^{\circ} \sim 20^{\circ}\end{array}$ & $\left.\begin{array}{l}3.4 \\
3.2\end{array}\right\} 6.6$ & $\left.\begin{array}{r}12.8 \\
8.0\end{array}\right\} 20.8$ \\
\hline $\begin{array}{l}20^{\circ} \sim 25^{\circ} \\
25^{\circ} \sim 30^{\circ}\end{array}$ & $\left.\begin{array}{l}5.1 \\
5.3\end{array}\right\} 10.4$ & $\left.\begin{array}{l}2.3 \\
0.7\end{array}\right\} \quad 3.0$ \\
\hline $\begin{array}{l}30^{\circ} \sim 35^{\circ} \\
35^{\circ} \sim 40^{\circ}\end{array}$ & $\left.\begin{array}{r}8.9 \\
12.1\end{array}\right\} 21.0$ & $c \wedge Z=45^{\circ}, \quad 2 \mathrm{~V}(t)=50^{\circ} \quad 0$ \\
\hline $\begin{array}{l}40^{\circ} \sim 45^{\circ} \\
45^{\circ} \sim 50^{\circ}\end{array}$ & $\left.\begin{array}{l}17.6 \\
29.1\end{array}\right\} 46.7$ & $\begin{array}{l}\text { 単斜輝石 (a) } \text { ， 2V }(-)=60^{\circ} \\
\text { の斜方輝石 (b) の等消光角線吕 }\end{array}$ \\
\hline $\begin{array}{l}50^{\circ} \sim 55^{\circ} \\
55^{\circ} \sim 60^{\circ}\end{array}$ & $\left.\begin{array}{l}7.5 \\
1.2\end{array}\right\} 8.7$ & $\begin{array}{l}\text { ら計算した任意断面における消 } \\
\text { 光角 } \mathrm{c} \wedge Z^{\prime} \text { の百分象頻度分布 }\end{array}$ \\
\hline & 100.0 & について頻度分布をしらべる。 \\
\hline
\end{tabular}




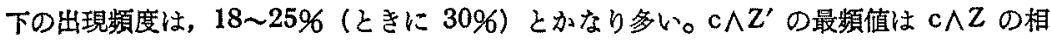
異によつてことなる。第 2 眓恃石基耀石方斜方輝石のみからなる岩石 (Ve, VIe, VIIIe 型）における $\mathrm{c} \wedge Z^{\prime}$ の頻度分布をしめす。輝石の任意断面にお汁る消光角 $\mathrm{c} \wedge Z^{\prime}$ の式

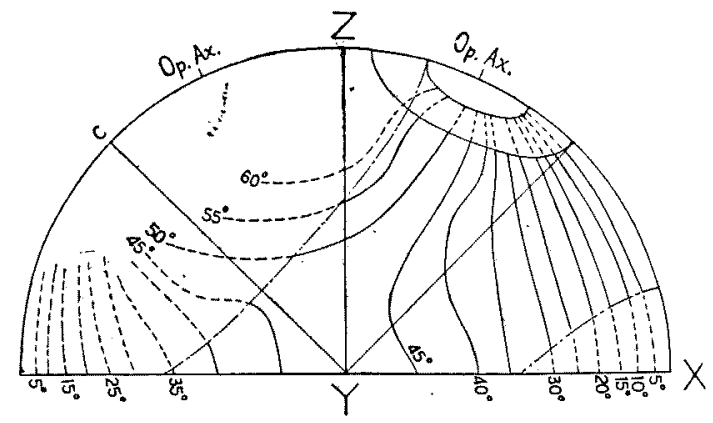

第 3 図

$\mathrm{c} \wedge Z=45^{\circ}, 2 \mathrm{~V}(t)=50^{\circ} \circ$ 単斜竨石(上) と, $2 \mathrm{~V}(-)=60^{\circ}$

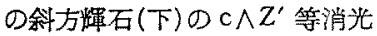
角線の等面積ステレオ投影，鎠 線の小円は $\mathrm{c}$ 軸と $30^{\circ}$ の傾き をなす面への法線の軌䟽をあら わす。(Op.Ax. 梳光軸)
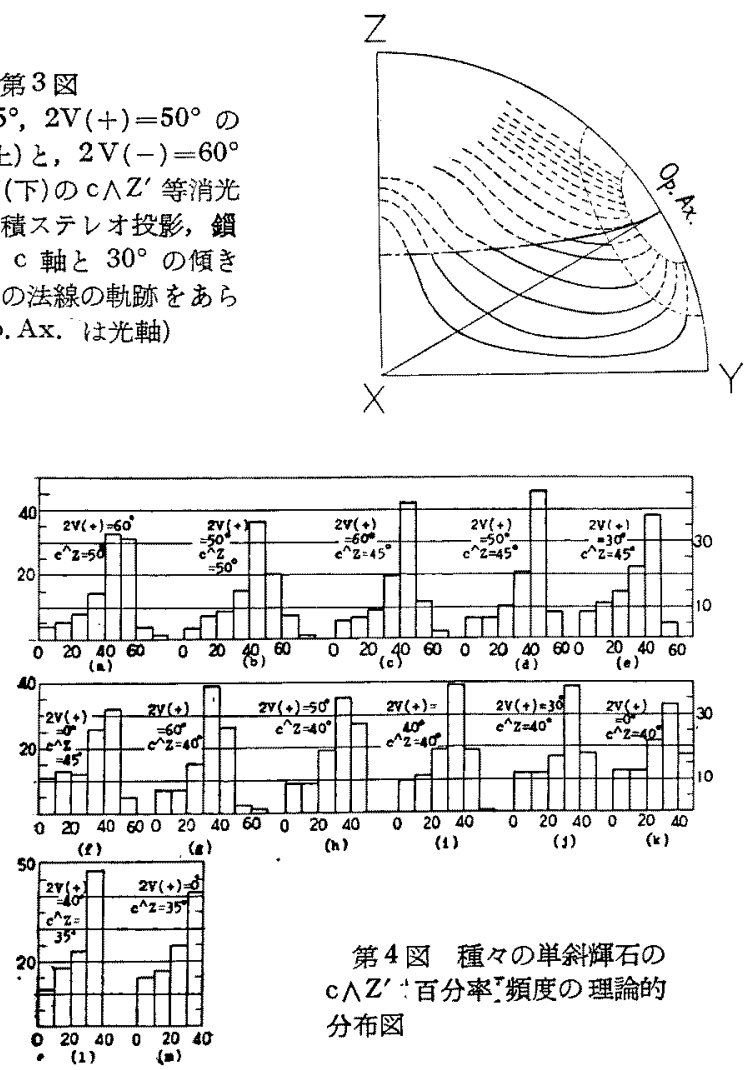

第 4 図種々の単斜輝石の $c \wedge Z^{\prime}:$ 百分率?頻度の理論的 分布図 
(竹下 1957)により，数值計算をおこない，等面積ステレオ網のうえに，等消光角線をえ がくことができる。第 3 図は, $2 V(+)=50^{\circ}, c \wedge Z=45^{\circ}$ の単斜輝石と $2 V(-)=60^{\circ}$ の 紫蘇䗒石の等消光角線の投影図である。結晶の断面が $\mathrm{c}$ 軸との傾き $30^{\circ}$ 以内の範囲をと

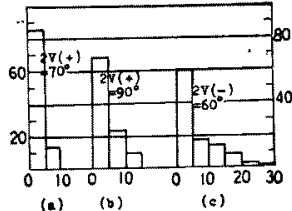

第 5 図種々の斜方輝石の $c \wedge Z^{\prime}$ 百分率 頻度の理論的分布図

り、また光軸ふきんでは，断面と光軸との傾き $70^{\circ} \sim 90^{\circ}$ の範囘をのそき，各等消光角線の間 の面皘察を測ることによつて，第 1 表のよう に, $\mathrm{c} \wedge Z^{\prime} の$ 百分家頻度をうる。他の光学 恒数をもつ輝石についても同じ方法で $c \wedge Z^{\prime}$ 百分率頻度分布をえ，これを第 4，5図にし めした。その他の光学恒数のばあいには，内雨・ 外插によつて，概略の頻度分布をうる。第 6 図 は，この内捙と外插に便である。第 1,2 図を 第 4,5 図とくらべると，実察の $\mathrm{c} \wedge Z^{\prime}$ 頻度 分布は，理詥的な頻度分布（第 4,5 図）とよ く一致することがわかる。とくに，第1図 (a)， (d)，(g)，第 2 図 (d) は文献（応地 1962，杉 1938，1951，八木・八木 1958) 加ら知りえた光学恒数加ら判断して，実際と理諭との 一致がよくうかがわれる。

\section{3. カルクアルカリ筫火山崖の石基輝石の $\mathrm{c} \wedge \mathbf{Z}^{\prime}$ 頻度分布}

斜方・単斜各輝石の $\mathrm{c} \wedge Z^{\prime}$ 頻度分布の相異により，両輝石がともに存在するばあいに は，両者の存在する割合に応して $\mathrm{c} \wedge Z^{\prime}$ が $0^{\circ} \sim 10^{\circ}$ および $30^{\circ} \sim 40^{\circ}$ または $40^{\circ} \sim 50^{\circ}$ と，一般に $2 つ の$ 最頻值をもつ頻度分布㚙えられる。この分布の相異を数量的にあつかい， 斜方・単斜雨輝石の鈜物比を推定することを試みる。

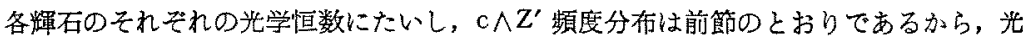
学恒数の知られた斜方・単斜雨輝石が特定の割合でまじりあつたばあいのcへZ' 理論的

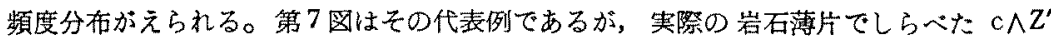
分布（第8図）とその形がよく一致している。一般に $20^{\circ}$ 付近に分布の明瞭な境界がみ られる。ある岩石の石基単斜蜖石のみの $0^{\circ} \sim 20^{\circ}$ 累積 百分率を $m$ ，石基斜方輝石のみ のそれをナとすればこの岩石潽片でしらへたた $\mathrm{c} \wedge Z^{\prime} の 0^{\circ} \sim 20^{\circ}$ 累積頻度 $y(\%) は$ ， 


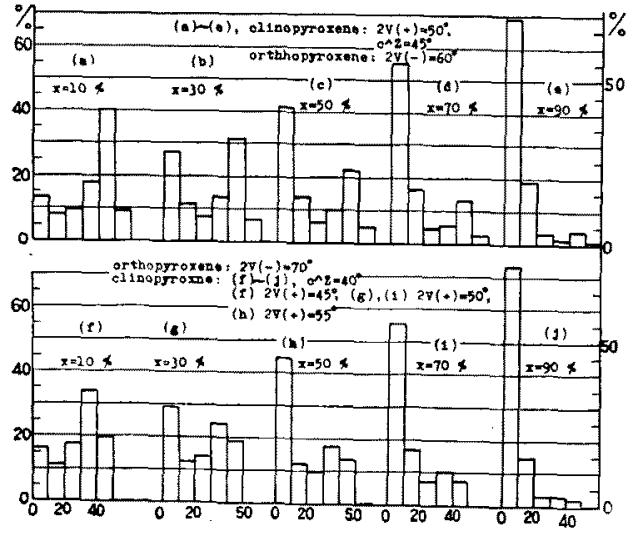

第7図 種マの斜方輝石量にたいする輝石の $\mathrm{c} \wedge Z^{\prime}$ の理論的 頻度分布図

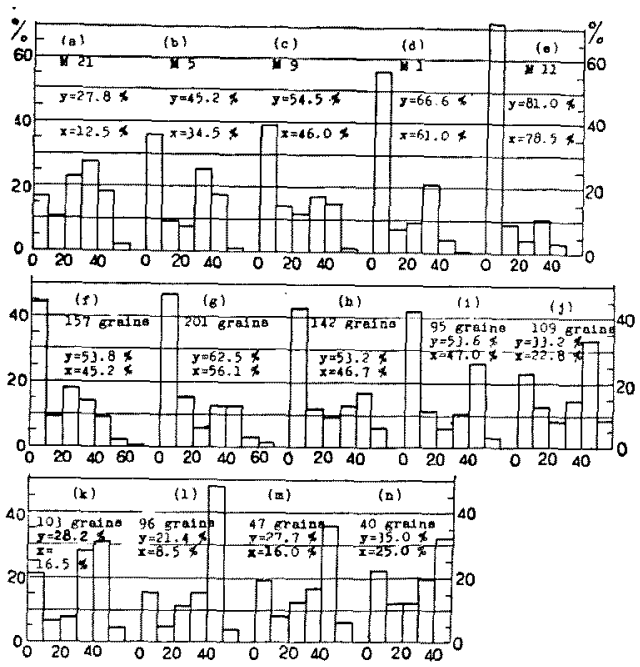

第 8 図 種々の斜方楎石量をしめすカルクアルカリ岩石基輝 石の $c \wedge Z^{\prime}$ 頻度分布の実例， (a) ～(e) 長野市貉䐚路安山岩， 岩体の周辺部をなすもの，(f)〜（n) 萩市笠山下部熔岩の輝 石の $\mathrm{A} \wedge Z^{\prime}$ 頻度分布，輝石の大きさ（c軸にそう長さ）こと に分布をしらべた例，（f） $0.01 \sim 0.02 \mathrm{~mm} ，$ (g) $0.02 \sim 0.03$ $\mathrm{mm}$, (h) $0.03 \sim 0.04 \mathrm{~mm}$, (i) $0.04 \sim 0.05 \mathrm{~mm}$, (J) 0.05 $\sim 0.06 \mathrm{~mm}$, (k) $0.06 \sim 0.09 \mathrm{~mm}$, (l) $0.09 \sim 0.13 \mathrm{~mm},(\mathrm{~m})$ $0.13 \sim 0.18 \mathrm{~mm}, \quad(\mathrm{n}) \quad 0.18 \sim 0.24 \mathrm{~mm}$ 
斜方耀石量 $x(=\mathrm{Rh} \times 100 /(\mathrm{Rh}+\mathrm{Mo})$ ，Rh は斜方辉石，Moは篻斜輝石の割合または 計数) $の 1$ 次式

$$
y=a x+m
$$

であらわされる。ここに $a=(r-m) / 100 ， r, m$ はそれをれ斜方辉石，単斜輝石の光学恒

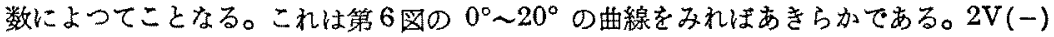

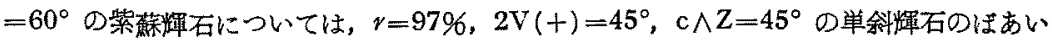
$m=16 \%$ (第6図加ら補䦭によつて求めた)。この両輝石からなる岩石では， $a \div 0.8$ と なる。第 9 园の直線 A は $\gamma=97 \%, m=15 \%\left(2 \mathrm{~V}(+)=50^{\circ}, \mathrm{c} \wedge \mathrm{Z}=45^{\circ}\right)$ のぼあい, 直線 $\mathrm{B}$ 注 $r=98 \%\left(2 \mathrm{~V}(-)=70^{\circ}, \mathrm{F} \mathrm{c} \wedge \mathrm{Z}=0^{\circ}\right), m=18 \%\left(2 \mathrm{~V}(+)=50^{\circ}, \mathrm{c} \wedge \mathrm{Z}=40^{\circ}\right)$ のばあいいいて，それでれ $c \wedge Z^{\prime}$ 分布からえた y の做により! フである。単斜輝石の $\mathrm{c} \wedge Z$ は $\mathrm{c} \wedge Z^{\prime}$ 分布から推定され，また普通の侢光㩆微鏡下でも 測れるので(千紫色の高いものをえらぶまたしばしばみられる(100) 双晶の接合線 により対称消光角か゚えらばれるばあいには，とくに好都合である)，曾通のカルクアルカ リ岩のぼあい（石基腪石は，普通輝石 $2 \mathrm{~V}(+)=45^{\circ} \sim 60^{\circ}$ と紫蘇輝石 $2 \mathrm{~V}(-)=70^{\circ} \sim 50^{\circ}$

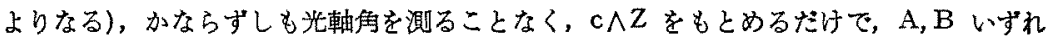

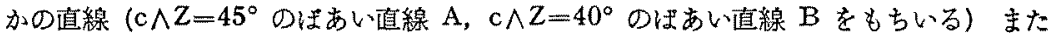
は两直線の中間の部分をもちいて，斜方輝石量 $x$ を推定しうる。第 8 図には，このよう にして推定した斜方輝石量をしめす。

おもに抽出による $y$ の俱差を $\Delta y$ とすると，xの頡差 $\Delta x$ は（1）式上り

$$
\Delta x=(1 / a) \cdot \Delta y
$$

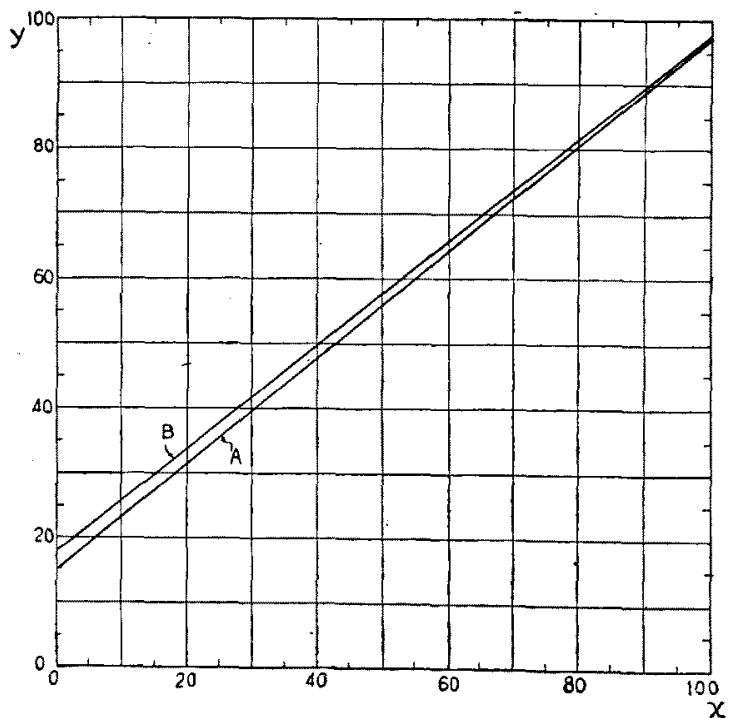

第9図 $0^{\circ}$ から $20^{\circ}$ までの $\wedge \wedge Z^{\prime}$ 累栍 百分率yと斜方輝 石量 $x(=\mathrm{Rh} \times 100 /(\mathrm{Rh}+\mathrm{Mo}))$ との関係図 
によつてあたえられる。 $y$ は鉱物の計数によつてえられた值であるから，その俱差 $\Delta y$ は， 信頼区間をしめす Manning (1953) の式によつてあたえられる。ある母集団における特 定の鉣物の出現頻度が P であるばあい，そのなかから全铌物を $\mathrm{N}$ 粒だ計数し，その

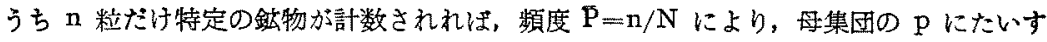
る信頼区間は，次式によつてあたえられる。

$$
\begin{aligned}
\mathrm{P}\left\{\left[\sin \left(\sin ^{-1} \sqrt{\mathrm{P}}-t_{\gamma / 2} \cdot(1 / 2 \sqrt{\mathrm{N}})\right)^{2}\right] \leqq \mathrm{p} \leqq\right. \\
\left.\left.\sin \left(\sin ^{-1} \sqrt{\mathrm{P}}+t_{\gamma / 2} \cdot(1 / 2 \sqrt{\mathrm{N}})\right)^{2}\right]\right\}=\gamma
\end{aligned}
$$

$こ こ に$

$$
\gamma=1 / \sqrt{2 \pi} \int_{-t^{r / 2}}^{+t_{r / 2}} e^{-t^{2} / 2} d t
$$

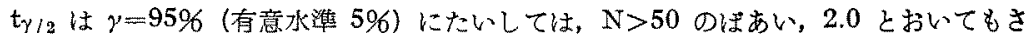
しつかえない。 Manning はこの式にもとずいて数值計算をおこない，種々の n/Nにた いし，計数 N のばあいの confidence belt をしめす图表を作成しだ。彼の図表をよむ

\begin{tabular}{|c|c|c|c|c|c|c|c|}
\hline$N$ & $(\mathrm{n} / \mathrm{N}) \times 100$ & 信 頼区間 & $\pm y$ & $\mathrm{~N}$ & $\begin{array}{c}(\mathrm{n} / \mathrm{N}) \times 100 \\
\%\end{array}$ & 信頼区 & $\pm \mathrm{y}$ \\
\hline 50 & $\begin{array}{l}15 \\
30 \\
50 \\
70 \\
15\end{array}$ & $\begin{array}{r}7.0 \sim 28.0 \\
18.0 \sim 45.0 \\
35.0 \sim 65.0 \\
55.0 \sim 82.4 \\
8.5 \sim 24.1\end{array}$ & $\begin{array}{rr} \pm & 10.5 \\
\pm & 13.5 \\
\pm & 15.0 \\
\pm & 13.7 \\
\pm & 7.8\end{array}$ & 250 & $\begin{array}{l}15 \\
30 \\
50 \\
70 \\
15\end{array}$ & $\begin{array}{l}11.0 \sim 20.0 \\
24.5 \sim 36.5 \\
43.7 \sim 56.3 \\
64.1 \sim 75.5 \\
12.0 \sim 19.0\end{array}$ & $\begin{array}{l}4.5 \\
6.0 \\
6.3 \\
5.7 \\
3.5\end{array}$ \\
\hline & $\begin{array}{l}30 \\
50 \\
70\end{array}$ & $\begin{array}{l}21.0 \sim 40.0 \\
40.0 \sim 60.0 \\
60.0 \sim 79.0\end{array}$ & $\begin{array}{lr} \pm & 9.5 \\
\pm & 10.0 \\
\pm & 9.5\end{array}$ & & $\begin{array}{l}30 \\
50 \\
70\end{array}$ & $\begin{array}{l}26.0 \sim 35.0 \\
45.0 \sim 55.0 \\
65.0 \sim 74.0\end{array}$ & $\begin{array}{l}4.5 \\
5.0 \\
4.5\end{array}$ \\
\hline
\end{tabular}
と, 95\% 信頼区間と標淮樭差 さyはつきの通りである。

第 2 表

(2) 式により $\Delta x$ が計算できる。 $\Delta x$ は一般に $\Delta y$ よりやや大きい。しかし自在回䎐合 をもちいて総計数 N のなか力ら，斜方輝石の計数 $\mathrm{n}$ を確実にえたとしても，母集団に おける斜方輝石量注前述の鿁差 $\Delta y$ に匹敵するものである。

\section{4. 本方法の適用と今後の課題}

本方法は，結晶質の火山岩（ガラスの量を無視できるもの）に適用すれば，岩石成因こ とにマグマの冷却過程の理解を十分ならしめる。長野市西方の貉鄉路採石場の岩䝺状岩体 はビジオン煇石斑晶を有する火山岩として，八木・八木(1958)によつて記載された。 筆者はこの岩体の露頭のほほ全域にわたつて禿統的なサンプリングをおこない，その薄片 について本方法を試みた。その結果，岩体の中心部(VC型) は石基輝石がすへて単斜輝 石であるにもかかわらず，周辺部（Vd 型）红斜方・単斜雨輝石からなり，斜方輝石量 $x$ は，10〜90\%（なかには痕跡程度に石基斜方輝石をふくむものがある）にわたつて変化 するにもかかわらず，化学組成はほとんど実駼摆差内て一致し，ただ $\mathrm{FeO}$ と $\mathrm{Fe}_{2} \mathrm{O}_{3}$ の 量比にわずかな差がるれる。この点に関連して, 石基斜方輝石量を岩石成因考察の一助

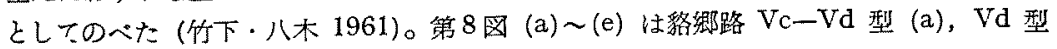


((b)，(c)，(d)，(e)）岩石の石基辉石の $\mathrm{c} \wedge Z^{\prime}$ 分布の代表例である。これらはいずれも 岩 (泥岩) との接触部加ら数 $\mathrm{m}$ 内外の周辺からの試料である。(d) は急冾周辺部の試料 で暗色を是するガラス筫岩であるが，他はみな明灰色結晶䁈である。これらの化学組成は 汪とんど変りないことが 2,3 の分析結果と㩆微競的特街とから判定される。それにもか かわらず石基斜方輝石量は変化にとみ、ことに周辺ほと大きな值をしめす。これ注进入し たばかりのマグマの周辺ほどガス圧の影響を多くこうむり，そのため低温区域の輝石 （斜方輝石）が多く晶出したものと解积している。

今後, 本方法をカルクアルカリ火山岩に広く適用し, 岩石成因論や火山層序学に資した w。

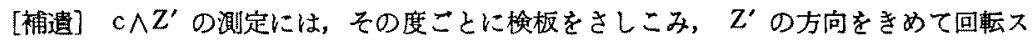
テージを右あるいは左にまわして，結晶を消光位にもならさねばならない。しかし，检板 をさしこむこと店く，ステーシをつねに右にあるいはつねに左にまわすよう各自できめ

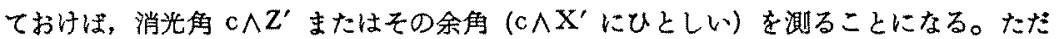
し，回転角が $70^{\circ}$ 以上になるばあいには，つねにまわす方向とは反対の方向にまわし，

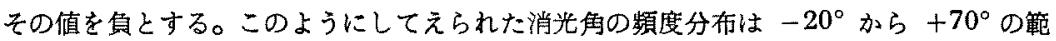
囲にわたり，第 1,2 図あるい第 4,5 図の分布のうえにさらにこれらの分布を裹返し にした形を加えることになるので，対称性のある山型分布となる。これ悌 7，8 図につ いても同しことである。単斜輝石の $\mathrm{c} \wedge Z^{\prime}$ が $70^{\circ}$ 以上になることは，特別なばあい

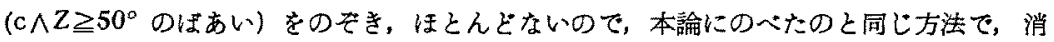
光角 $\mathrm{c} \wedge Z^{\prime}$ とその余角の $-20^{\circ} \sim+20^{\circ}$ 累積 百分率 $y(96)$ をうれば，(1) 式によ

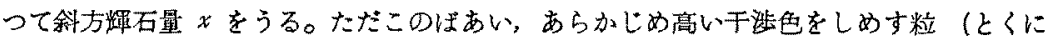
(100) 双晶により対称消光角のえられるものがよい) について，c^Z值を測つておく必 要はある。

この簡易化された方法によると，精度はすこしもそこなわれることなく，検板の出し入 れにわずらわされないので，一層迅速に測定をおこなうことができる。

謝辞： 終始指導いただいている北海道大学理学部八木健三教授に，また昭和新山の試 料を提供いたたいた三松正夫氏に心からなる謝意を表する。

\section{引用 文 献}

久野 久 (1954)，火山及て゚火山岩，岩波全畫，200２19.

Manning, J.C. (1953), Application of statistical estimation and hypothesis testing to geological data, Jour. Geol., 61, 544 556.

応地善堆 (1962)，北九州地域の新生代玄武岩類の岩石学的研究，岩鉣，47, 23〜35.

杉 健一 (1938)，四国高松付近の䜅蚑岩類，特にその中の Xenocrystに就いて， 火山, 4,17〜33.

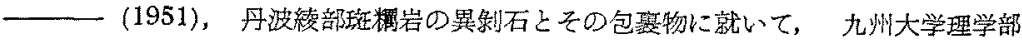
研究報告, 3, 2 .

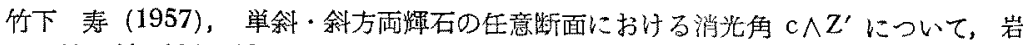
鋶, 41, 181 184.

竹下 表·八木健三 (1961)，長野古貉郷路安山岩の鉱物組成と化学組成，乙くにそ の成因的考察，火山，II, 6, 70 85.

八木貞助・八木健三 (1958), 上水内郡地筫誌, 上水内教育会. 